\title{
Z prawnej problematyki gospodarowania na dzierżawionych gruntach rolnych
}

Dzierżawa jest popularną na wsi formą władania gruntami rolnymi. Jej przedmiotem mogą być zarówno nieruchomości prywatne, jednostek samorządu terytorialnego, jak i Skarbu Państwa. Status wydzierżawiającego ma wpływ na regulacje prawne kształtujące stosunek prawny dzierżawy gruntów rolnych. Przepisy dotyczące samej umowy dzierżawy zawarte są w kodeksie cywilnym (od art. 693 do 709 kc.). Natomiast prawo pierwokupu przysługujące dzierżawcy określone zostało w ustawie z dnia 11 kwietnia 2003 r. o kształtowaniu ustroju rolnego ${ }^{2}$. Regulacje te mają zastosowanie przede wszystkim do tzw. dzierżawy ,prywatnej”. Jeżeli chodzi o dzierżawę gruntów rolnych od jednostek samorządu terytorialnego, to oprócz wspomnianych aktów prawnych stosujemy także ustawę z dnia 21 sierpnia $1997 \mathrm{r}$. o gospodarce nieruchomościami ${ }^{3}$. Z kolei dzierżawa tzw. „państwowa od ANR” została uregulowana w ustawie z dnia 19 października 1991 r. o gospodarowaniu nieruchomościami rolnymi Skarbu Państwa $a^{5}$ oraz w wydanych na jej podstawie aktach wykonawczych ${ }^{6}$.

Obecnie obowiązujące przepisy prawne odnoszące się do dzierżawy gruntów rolnych są zatem zróżnicowane. $\mathrm{Z}$ tego powodu gospodarowanie, czyli prowadzenie działalności rolniczej na takich gruntach nie jest łatwe i łączy się koniecznością znajomości wielu rozwiązań prawnych ${ }^{7}$. W ostatnich latach zauważyć należy tak-

\footnotetext{
Uniwersytet Przyrodniczy w Poznaniu.

Dz.U. Nr 64, poz. 592 z późn. zm.

Tekst jedn. Dz.U. z 2004 r. Nr 261, poz. 2603 z późn. zm.

Dzierżawa tzw. „państwowa” związana była z dzierżawą gruntów z Państwowego Funduszu Ziemi, a od roku 1992 od Agencji Własności Rolnej Skarbu Państwa. Z kolei następca prawnym wymienionej państwowej osoby prawnej po wejściu w życie ustawy z dnia 11 kwietnia 2003 r. o kształtowaniu ustroju rolnego jest Agencja Nieruchomości Rolnych, zwana dalej ANR albo Agencją.

$5 \quad$ Tekst jednolity Dz.U. z 2007 r. Nr 231, poz. 1700 z późn. zm. (zwana dalej ustawą z 19 października 1991 r.).

6 Rozporządzenie Ministra Rolnictwa i Rozwoju Wsi z 19 listopada 2009 r. w sprawie szczegółowych przesłanek odroczenia, rozłożenia na raty lub umorzenia należności Agencji Nieruchomości Rolnych oraz trybu postępowania w tych sprawach (Dz.U. Nr 210, poz. 1619 ze zm.), Rozporządzenie Ministra Rolnictwa i Rozwoju Wsi z dnia 14 stycznia 2009 r. w sprawie szczegółowego trybu przeprowadzania przetargów na dzierżawę nieruchomości Zasobu Własności Rolnej Skarbu Państwa (Dz.U. Nr 17, poz. 93). ka, jak i grunty dzierżawione od sąsiada, ANR oraz gminy.
} 
że ewolucje ustawodawstwa unijnego i polskiego odnośnie do wymagań, jakie musi spełnić władający gruntami rolnymi (a więc także posiadacz zależny), aby otrzymać środki unijne ${ }^{8}$. Mimo występujących w praktyce problemów prawnych dzierżawa gruntów rolnych jest popularną formą organizowania i prowadzenia gospodarstw rolnych. Do wzrostu jej znaczenia przyczyniła się bezsprzecznie działalność ANR. Przejęła ona do końca grudnia 2010 r. nieruchomości o powierzchni ponad 4,7 mln ha, z tego w dzierżawie było ponad 1,54 mln ha ${ }^{9}$. Warto dodać, że w niektórych latach w posiadaniu dzierżawców było ponad 2 mln państwowych gruntów rolnych, np. w 1995 r. 2 mln 745 tys. ha, w 1996 r. 2 mln 928 tys. ha, 1998 r. 2 mln 810,5 tys. ha, 2002 r. 2 mln 407, 5 tys. ha ${ }^{10}$.

Podjęcie tematu poświęconego gospodarowaniu na dzierżawionych gruntach rolnych uzasadniają przede wszystkim względy praktyczne związane z zainteresowaniem rolników zawarciem umowy dzierżawy, problemami, z którymi stykają się dzierżawcy, a także zmiany przepisów prawnych. Tytułem przykładu warto wymienić ostatnią nowelizację ustawy z 16 września 2011 r. o gospodarowaniu nieruchomościami rolnymi Skarbu Państwa, ${ }^{11}$ modyfikującą także ustawę z 11 kwietnia 2003 r. o kształtowaniu ustroju rolnego, która wprowadziła instrumenty zagrażające stabilności dzierżawy.

Celem artykułu jest zatem próba odpowiedzi na pytanie, czy przepisy zapewniają producentowi rolnemu (dzierżawcy) wystarczającą trwałość gospodarowania na dzierżawionych gruntach rolnych. W tym miejscu warto wyjaśnić, że ,trwałość gospodarowania na dzierżawionych gruntach rolnych" oznacza prowadzenie stabilnej działalności rolniczej przez rolnika na dzierżawionych gruntach rolnych. Można przyjąć, że na ową trwałość składają się dwa elementy: zagwarantowanie producentowi rolnemu ciągłości posiadania i pobierania pożytków z gruntów rolnych oraz zapewnienie zdolności produkcyjnej przedmiotu dzierżawy ${ }^{12}$.

Ograniczone ramy artykułu nie pozwalają na wyczerpujące omówienie wspomnianych elementów. Zostaną zatem wybrane niektóre zagadnienia, szczególnie te związane $\mathrm{z}$ oceną wpływu rozwiązań prawnych zawartych w ustawie $\mathrm{z}$ dnia 16 września 2011 r. o zmianie ustawy o gospodarowaniu nieruchomościami rolnymi Skarbu Państwa na trwałość stosunku prawnego dzierżawy gruntów rolnych oraz $\mathrm{z}$ instrumentami prawnymi zachowania zdolności produkcyjnej przedmiotu dzierżawy.

Szczególnie zmiany nastapiły w zakresie pomocy udzielanej w ramach płatności bezpośrednich. Jest to m.in. wynikiem wprowadzenia zasad wzajemnej zgodności (ang. cross-compliance).

9 Informacje dotyczące zagospodarowania gruntów Zasobu WRSP dostępne są na stronie internetowej Agencji Nieruchomości Rolnych http://www. anr.gov.pl

10 Tak W. Poczta, P.B. Nowak, Zasady i skutki odtworzenia majątku Zasobu Własności Rolnej Skarbu Państwa w dzierżawie, Poznań 2007, s. 29-31.

11 Dz.U. Nr 233 poz. 1382, zwana dalej nowelizacją z 16 września 2011 r.

12 Na temat pojęcia „trwałość gospodarowania na dzierżawionych gruntach rolnych” zob. szerzej A. Suchoń, Prawna ochrona trwałości gospodarowania na dzierżawionych gruntach rolnych, Poznań 2006, s. 5 i n. 
2. Zagadnienie stabilnego posiadania i pobierania pożytków z dzierżawionych gruntów rolnych przez rolnika rozpatrywać należy w kontekście ochrony trwałości stosunku prawnego dzierżawy gruntów rolnych oraz ułatwienia dzierżawcy nabycia własności dzierżawionych gruntów rolnych. Ochrona trwałości stosunku prawnego dzierżawy gruntów rolnych polega na zagwarantowaniu jego trwania w czasie. Odpowiednia ochrona zapewnia dzierżawcy pozycję samodzielnego producenta rolnego, stabilizację, zachęca go do prowadzenia racjonalnej gospodarki na gruncie dzierżawionym i pozwala na wieloletnie planowanie inwestycyjno-produkcyjne. Natomiast ułatwienie dzierżawcy nabycia własności dzierżawionych gruntów rolnych wyraża się poprzez wprowadzenie przez ustawodawcę odpowiednich instytucji, takich jak chociażby prawo pierwokupu czy pierwszeństwo nabycia. Jak pokazuje praktyka, dzierżawcy chętniej podejmują się wykonania inwestycji na dzierżawionych gruntach rolnych, stosują nowocześniejsze metody uprawy gruntów rolnych, gdy mają gwarancje, że w przyszłości będą mogli nabyć własność dzierżawionych gruntów rolnych. Co prawda, nabycie własności dzierżawionych gruntów rolnych prowadzi do zakończenia dzierżawy, ale powoduje powstanie trwałej jednostki produkcyjnej.

Po dokonaniu analizy nowelizacji ustawy o gospodarowaniu nieruchomościami rolnymi Skarbu Państwa z dnia 16 września 2011 r., która weszła w życie 3 grudnia 2011 r., stwierdzić należy, że dzierżawa jako forma gospodarowania państwowymi gruntami rolnymi będzie coraz mniej stabilna dla dzierżawcy. Warto wskazać, że ANR w terminie 6 miesięcy od dnia wejścia w życie nowelizacji, przedstawi dzierżawcom, w formie pisemnego zawiadomienia, propozycję dokonania zmian tej umowy w zakresie wyłączenia z dzierżawy $30 \%$ powierzchni użytków rolnych będących przedmiotem dzierżawy. Procedury tej nie stosuje się do umów dzierżawy zawartych przed dniem wejścia w życie niniejszej ustawy, w przypadku gdy: łączna powierzchnia użytków rolnych Zasobu Własności Rolnej Skarbu Państwa dzierżawiona przez danego dzierżawcę w dniu wejścia w życie niniejszej ustawy po dokonaniu wyłączenia nie przekraczałaby 300 ha. ANR przyjmuje, że wyłączenia będą dotyczyły zatem umów, gdy przedmiot dzierżawy przekroczy 429 ha. Gdyby wszyscy dzierżawcy objęci wyłączeniem wyrazili zgodę na modyfikację umowy, Zasób WRSP zostałby powiększony o następujące powierzchnie gruntów rolnych (według województw): dolnośląskie 19 tys. ha, kujawsko-pomorskie 11 tys. ha, lubelskie 2,5 tys. ha, lubuskie 9 tys. ha, łódzkie 0,8 tys. ha, małopolskie 0,2 tys. ha, mazowieckie 0,5 tys. ha, opolskie 15 tys. ha, podlaskie 0,5 tys. ha, pomorskie 12,5 tys. ha, śląskie 1 tys. ha, świętokrzyskie 0,15 tys. ha, warmińsko-mazurskie 16 tys. ha, wielkopolskie 28 tys. ha, zachodniopomorskie 30 tys. ha.

Trudno oczywiście przewidzieć, ilu posiadaczy zależnych wyrazi zgodę na propozycję ANR w zakresie modyfikacji przedmiotu umowy. Niemniej jednak regulacje zawarte w nowych przepisach stawiają dzierżawców w trudnej sytuacji i ne- 
gatywnie wpływają na zachowanie trwałości gospodarowania na dzierżawionych gruntach rolnych. W przypadku niewyrażenia zgody na zmianę umowy czy też niedokonania zmiany umowy dzierżawy z przyczyn leżących po stronie dzierżawcy, nie stosuje się: prawa pierwszeństwa nabycia nieruchomości bez przetargu oraz przedłużenia dzierżawy po zakończeniu okresu określonego w umowie bez konieczności przeprowadzenia przetargu. Zatem dzierżawca, który nie wyrazi zgody na zmianę warunków umowy, musi liczyć się faktem, że upływ terminu umownego oznacza koniec prowadzenia działalności rolniczej na dzierżawionych gruntach rolnych. Korzystanie bezumowne z gruntów po tym terminie łączy się z wysokimi opłatami. Według bowiem dodanego ust. 6 do art. 39 ustawy z 19 października 1991 r. osoba władająca nieruchomością wchodzącą w skład Zasobu bez tytułu prawnego jest zobowiązana do zapłaty na rzecz Agencji wynagrodzenia za korzystanie z tej nieruchomości w wysokości stanowiącej 5-krotność wywoławczej wysokości czynszu, który byłby należny od tej nieruchomości, gdyby była ona przedmiotem umowy dzierżawy po przeprowadzeniu przetargu. Wysokość wynagrodzenia ustala się na dzień, w którym Agencja zażądała zwrotu nieruchomości.

W przypadku dokonania zmiany umowy dzierżawy dzierżawcy przysługuje uprawnienie do zakupu całości albo za zgodą ANR części nieruchomości, która pozostała przedmiotem dzierżawy, w brzmieniu nadanym niniejszą ustawą, z zastosowaniem prawa pierwszeństwa niezależnie od faktycznego czasu trwania umowy dzierżawy. Warto przypomnieć, że co do zasady prawo pierwszeństwa przysługuje po 3 latach trwania dzierżawy. Dzierżawca może nabyć grunty, które użytkuje w terminach określonych w nowelizacji. Ustawodawca uzależnił je od czasu trwania umowy dzierżawy (od 3 miesięcy do 6 lat). Zauważyć jednak należy, że uprawnienie do nabycia następuje z zastosowaniem prawa pierwszeństwa. Jak wiadomo, z prawa tego w pierwszej kolejności może skorzystać były właściciel albo jego spadkobierca. Wynika to z art. 29 ust. 1 ustawy z 19 października 1991 r. Kolejna bariera w zakresie nabycia gruntów od ANR zawarta jest w art. 28a ustawy. W jego świetle sprzedaż nieruchomości rolnej przez Agencję może nastąpić, jeżeli w wyniku tej sprzedaży łączna powierzchnia użytków rolnych będących własnością nabywcy nie przekroczy 500 ha.

Warto także zaznaczyć, że nawet jeżeli dzierżawca wyrazi zgodę na wyłączenie $30 \%$ gruntów z przedmiotu dzierżawy, to istotny problem może odnosić się do określenia konkretnego obszaru gruntów podlegającego wyłączeniu. W skład przedmiotu dzierżawy wchodzą przecież grunty różnej klasy bonitacyjnej, grunty zabudowane i niezabudowane. W wielu sytuacjach potrzebne będzie dokonanie dodatkowych prac geodezyjnych mających na celu wydzielenie działek podlegających wyłączeniu. ANR wraz z zawiadomieniem o wyłączeniu przesyła projekt zmiany umowy dzierżawy, określający działki ewidencyjne lub ich części, które proponuje wyłączyć z dzierżawy. Wydaje się, że dla zachowania stabilnego prowadzenia działalno- 
ści rolniczej bardziej zasadne byłoby wskazywanie obszaru podlegającego wyłączeniu przez dzierżawcę. Zgodnie ze znowelizowaną ustawą wyłączenie co do zasady ma nastąpić najpóźniej w ciągu roku od daty podpisania aneksu. Pozytywnie ocenić należy zasadę, że w odniesieniu do nieruchomości rolnych lub ich części, których dzierżawa jest niezbędna do wykonania obowiązków lub zobowiązań związanych z przyznaną danemu dzierżawcy przed dniem wejścia omawianej nowelizacji pomocą finansową współfinansowaną lub finansowaną $\mathrm{z}$ udziałem środków unijnych $^{13}$, termin wyłączenia użytków rolnych określa się najwcześniej na dzień następujący po dniu zakończenia przez dzierżawcę wykonywania tych obowiązków.

ANR (poprzednia nazwa to Agencja Własności Rolnej Skarbu Państwa) funkcjonuje już około 20 lat. W ciągu tego okresu wielokrotnie zmianie ulegały przepisy odnoszące się do form zagospodarowania mienia z Zasobu WRSP, w tym dzierżawy gruntów rolnych. Do instrumentów wpływających pozytywnie na trwałość gospodarowania na tych gruntach dzierżawionych zaliczyć można m.in. zawieranie umów na czas oznaczony, możliwość przedłużenia dzierżawy na kolejny okres dzierżawny, modyfikacje świadczenia czynszowego zgodnie z rozporządzeniem Ministra Rolnictwa i Rozwoju Wsi z 19 listopada 2009 r. w sprawie szczegółowych przesłanek odroczenia, rozłożenia na raty lub umorzenia należności ANR oraz trybu postępowania w tych sprawach ${ }^{14}$, zwolnienia z opłat czynszu na podstawie art. 40 ustawy z 19 października $1991 \mathrm{r}^{15}$

Stwierdzić należy, że większą stabilizację w zakresie prowadzenia działalności gospodarczej na dzierżawionych gruntach państwowych mają rolnicy indywidualni. Mogą oni przykładowo brać udział w przetargach ograniczonych na dzierżawę albo sprzedaż gruntów z Zasobu WRSP ${ }^{16}$.

Odnosząc się z kolei do dzierżawy prywatnych gruntów rolnych, stwierdzić trzeba, że strony umowy mają dużą swobodę w zakresie kształtowania treści kontraktu. Większość bowiem przepisów kodeksu cywilnego poświęconych dzierżawie ma charakter względnie obowiązujący. Oznacza to, że strony mogą w umowie dzierżawy gruntów rolnych zawierać postanowienia zapewniające im większą stabilizację w zakresie gospodarowania na dzierżawionych gruntach. Jak pokazuje jednak

13 Chodzi o środki z Europejskiego Funduszu Rolnego na rzecz Rozwoju Obszarów Wiejskich lub Europejskiego Funduszu Orientacji i Gwarancji Rolnej.

14 Zastapiło ono rozporządzenie Ministra Skarbu Państwa z dnia 1 sierpnia 2003 r. w sprawie szczegółowych przesłanek odroczenia, rozłożenia na raty lub umorzenia należności ANR oraz trybu postępowania w tych sprawach (Dz.U. Nr 140, poz. 1349).

Agencja może zwolnić dzierżawcę z opłat czynszowych na warunkach określonych w umowie, np. na okres nie dłuższy niż pięć lat, w przypadkach uzasadnionych stanem przedmiotu dzierżawy lub realizacją inwestycji tworzących nowe miejsca pracy.

Agencja może zastrzec, że w przetargu mogą uczestniczyć wyłącznie np.: rolnicy indywidualni, w rozumieniu przepisów o kształtowaniu ustroju rolnego, zamierzający powiększyć gospodarstwo rodzinne, jeżeli mają oni miejsce zamieszkania w gminie, w której położona jest nieruchomość wystawiana do przetargu lub w gminie graniczącej z tą gminą lub osoby posiadające kwalifikacje rolnicze określone w przepisach o kształtowaniu ustroju rolnego, zamierzające utworzyć gospodarstwo rodzinne w rozumieniu tych przepisów. 
praktyka, taki charakter przepisów wpływa z reguły negatywnie na pozycję dzierżawcy. Strony bowiem nie uzgadniają wielu istotnych kwestii w umowie, a gwarancje ochrony dzierżawcy zawarte w kodeksie cywilnym są niewystarczające. Odnosi się to szczególnie do takich kwestii, jak np. określenie czasu trwania dzierżawy, przedłużenie na następny okres dzierżawny, obniżenie czynszu dzierżawnego (art. 700 kc.), przesłanki wypowiedzenia dzierżawy, naprawy i ulepszenia przedmiotu dzierżawy, ciągłości dzierżawy w przypadku zmian osobowych po stronie umowy.

Omawiana nowelizacja z dnia 16 września 2011 r. zmieniła także niektóre przepisy ustawy z dnia 11 kwietnia 2011 r. o kształtowaniu ustroju rolnego. Przede wszystkim modyfikacji uległa definicja rolnika indywidualnego. Jest nim obecnie nie tylko właściciel i dzierżawca, ale także użytkownik wieczysty i posiadacz samoistny. Do powierzchni 300 ha wlicza się zatem nie tylko grunty będące własnością i dzierżawione, ale także te wynikające $\mathrm{z}$ umowy użytkowania wieczystego czy będące w posiadaniu samoistnym. Zmianie uległy także pojęcia „kwalifikacje rolnicze”, „samodzielne prowadzenie gospodarstwa rolnego"17. Takie modyfikacje spowodują, że mniej dzierżawców będzie miało status rolnika indywidualnego i w rezultacie będzie mogło nabyć grunty w ramach prawa pierwokupu. Niemniej jednak pozytywnie ocenić należy przepisy przejściowe, określające, że osoby fizyczne, które w dniu wejścia w życie nowelizacji z 16 września 2011 r. są rolnikami indywidualnymi w brzmieniu dotychczasowym, ale nie spełniają warunków zmienionej definicji rolnika indywidualnego, przez okres 5 lat uznaje się za osoby spełniające te warunki.

Analizowana nowelizacja wprowadziła do ustawy o kształtowaniu ustroju rolnego także art. 4a, zgodnie z którym prawo pierwokupu stosuje się odpowiednio przy przeniesieniu własności gospodarstwa rolnego, z tym że prawo pierwokupu dzierżawcy przysługuje wyłącznie dzierżawcy całego gospodarstwa rolnego. Wyjaśnić warto, że do czasu wejścia w życie nowelizacji odnotować należy wystę-

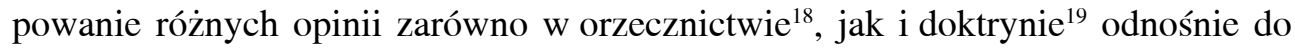
odpowiedzi na pytanie, czy dzierżawcy gruntów rolnych przysługuje prawo pierwokupu w przypadku sprzedaży części dzierżawionych gruntów rolnych. Przyznanie prawa pierwokupu wyłącznie dzierżawcy całego gospodarstwa rolnego w przypadku sprzedaży budzi wątpliwości. Biorąc pod uwagę, że ratio legis przyznania prawa pierwokupu dzierżawcy w ustawie z dnia 11 kwietnia 2003 r. była ochrona gospodarstw rodzinnych, stwierdzić trzeba, że wtedy gdy rozumiemy gospodarstwo rol-

Obecnie uważa się, że osoba fizyczna osobiście prowadzi gospodarstwo rolne, jeżeli: (a) pracuje w tym gospodarstwie; (b) podejmuje wszelkie decyzje dotyczące prowadzenia działalności rolniczej w tym gospodarstwie. Przed wejściem z życie nowelizacji z 16 września 2011 r. do osobistego prowadzenia gospodarstwa rolnego, wystarczyło podejmowanie wszelkich decyzji dotyczących prowadzenia działalności rolniczej w tym gospodarstwie. 
ne funkcjonalnie, nieruchomość rolna będąca przedmiotem dzierżawy nie wchodzi już w skład gospodarstwa wydzierżawiającego właściciela, lecz jest częścią gospodarstwa rolnego dzierżawcy ${ }^{20}$. Zasadne wydawało się przyjęcie, że dzierżawcy przysługuje prawo pierwokupu także w przypadku, gdy przedmiotem sprzedaży jest gospodarstwo rolne wydzierżawiającego, a dzierżawiona nieruchomość rolna stanowi jego część. Przemawia za tym interes społeczno-gospodarczy. Obecne brzmienie art. 4a ustawy o kształtowaniu ustroju rolnego pozbawiające dzierżawcę prawa pierwokupu dzierżawionej nieruchomości (stanowiącej część gruntów wydzierżawiającego) w przypadku sprzedaży całego gospodarstwa może prowadzić do rozbicia funkcjonalnie istniejącej całości gospodarczej dzierżawcy ${ }^{21}$.

Przechodząc z kolei do problematyki dzierżawy gruntów rolnych komunalnych, stwierdzić należy, że najmniejszą stabilizację stosunku prawnego dzierżawy mają właśnie dzierżawcy zawierający umowy z jednostkami samorządu terytorialnego. Przede wszystkim należy podkreślić, że przepisy ustawy z dnia 21 sierpnia 1997 r. o gospodarce nieruchomościami nie wprowadzają postanowień uwzględniających specyfikę rolną w zakresie użytkowania gruntów rolnych. Do samej treści umowy, praw i obowiązków stron kontraktu dzierżawy stosujemy przepisy kodeksu cywilnego. Umowy zawierane są z reguły na krótkie okresy. Ustawa z dnia 21 sierpnia 1997 r. nie przewiduje takich instytucji, jak chociażby przedłużenie dzierżawy na kolejny okres dzierżawny. Zgodnie z art. 37 ust. 4 ustawy o gospodarce nieruchomościami zawarcie umów użytkowania, najmu lub dzierżawy na czas oznaczony dłuższy niż 3 lata lub na czas nieoznaczony następuje w drodze przetargu. Ewentualnie wojewoda albo odpowiednia rada lub sejmik mogą wyrazić zgodę na odstąpienie od obowiązku przetargowego trybu zawarcia tych umów. $\mathrm{Z}$ tego to powodu gminy często zawierają umowy na krótkie okresy, np. 2 lat, a taka umowa nie daje dzierżawcy stabilizacji. Poza tym tak krótkie umowy, trwające poniżej 3 lat, nie gwarantują prawa pierwokupu. Nie ma także odrębnych przepisów dotyczących modyfikacji świadczenia czynszowego, jak ma to miejsce w odniesieniu do gruntów państwowych od ANR.

Spore kłopoty w praktyce wiążą się z możliwością nabycia dzierżawionych gruntów komunalnych na własność. Przepisy ustawy o gospodarce nieruchomościami do podmiotów, którym przysługuje prawo pierwszeństwa nabycia nieruchomości bez przetargu, nie zaliczają dzierżawców gruntów rolnych. Jedynie wojewoda (w odniesieniu do nieruchomości stanowiących własność Skarbu Państwa) bądź odpowiednia rada lub sejmik (w odniesieniu do nieruchomości stanowiących włas-

Tak S. Prutis, Glosa do uchwały..., s. 164. Zob też K. Stefańska, Określenie sytuacji prawnej nabywcy gospodarstwa rolnego, (w:) Prawo rolne. Problemy teorii i praktyki, pod red. R. Budzinowskiego, A. Zielińskiego, Kluczbork 2001, s. 229-230; J. Szachułowicz (w:) Kodeks cywilny. Komentarz, t. 2, Warszawa 2003, s. 292. 
ność jednostki samorządu terytorialnego), odpowiednio w drodze zarządzenia lub uchwały, mogą zwolnić $\mathrm{z}$ obowiązku zbycia w drodze przetargu nieruchomości, gdy sprzedaż nieruchomości następuje na rzecz osoby, która dzierżawi nieruchomość na podstawie umowy zawartej co najmniej na 10 lat, jeżeli nieruchomość ta została zabudowana na podstawie zezwolenia na budowę.

Jednocześnie, dokonując analizy ustawy o kształtowaniu ustroju rolnego, należy stwierdzić, że w przypadku sprzedaży komunalnych gruntów rolnych zastosowanie ma prawo pierwokupu dzierżawcy. Problem pojawia się jednak z realizacją tego prawa. Otóż w świetle ustawy o gospodarce nieruchomościami zbycie gruntów następuje w drodze przetargu. W pierwszej kolejności gmina zobligowana jest zatem ogłosić i przeprowadzić przetarg, w którym może brać udział także dzierżawca. Wydaje się, że w warunkach przetargu powinno zostać zaznaczone, że przedmiotem sprzedaży jest grunt rolny oddany w dzierżawę i zawarcie umowy przenoszącej własność nastąpi w przypadku nieskorzystania przez dzierżawcę z prawa pierwokupu. W przypadku wyboru w trybie przetargowym nabywcy, innego niż posiadacz zależny, przedmiot dzierżawy może być sprzedany osobie trzeciej tylko pod warunkiem, że uprawniony do pierwokupu, czyli dzierżawca, swego prawa nie wykona. Oznacza to, że jednostka samorządu terytorialnego może zawrzeć na początku z kupującym jedynie umowę zobowiązującą do sprzedaży. Następnie informuje o jej treści dzierżawcę, który w ciągu miesiąca może skorzystać z prawa pierwokupu i wstąpić w miejsce kupującego. $Z$ powodu skomplikowanej procedury stosunkowo rzadko gminy dokonują sprzedaży gruntów rolnych oddanych w dzierżawę. Najczęściej następuje to dopiero po zakończeniu umowy dzierżawy, gdy byłemu posiadaczowi zależnemu nie przysługuje już prawo pierwokupu.

Nie tylko ustawa o gospodarce nieruchomościami nie jest korzystna dla dzierżawców gruntów komunalnych. Takie samo stwierdzenie można wysunąć po analizie ustawy z dnia 15 listopada $1984 \mathrm{r}$. o podatku rolnym ${ }^{22}$. Co prawda według tego aktu prawnego podatnikami podatku rolnego są osoby fizyczne, osoby prawne, jednostki organizacyjne, w tym spółki, nieposiadające osobowości prawnej, będące m.in. posiadaczami gruntów, stanowiących własność Skarbu Państwa lub jednostki samorządu terytorialnego, jeżeli posiadanie wynika np. z umowy zawartej z właścicielem, jednak nie mogą oni skorzystać ze zwolnienia i ulgi w przypadku powiększenia gospodarstwa rolnego. Według bowiem art. 12 ustawy o podatku rolnym z podatku zwalnia się grunty przeznaczone na utworzenie nowego gospodarstwa rolnego lub powiększenie już istniejącego do powierzchni nieprzekraczającej 100 ha: (a) będące przedmiotem prawa własności lub prawa użytkowania wieczystego, nabyte w drodze umowy sprzedaży, (b) będące przedmiotem umowy o oddanie gruntów w użytkowanie wieczyste, (c) wchodzące w skład Zasobu Własności Rol- 
nej Skarbu Państwa, objęte w trwałe zagospodarowanie, przy czym za trwałe zagospodarowanie uważa się objęcie gruntów w dzierżawę lub użytkowanie na okres nie krótszy niż 10 lat.

Co więcej, w przypadku nabycia dzierżawionych gruntów od jednostki samorządu terytorialnego byli dzierżawcy nie mogą z reguły także skorzystać z omawianego zwolnienia. Przeważa bowiem interpretacja, że grunty te już wchodziły w skład gospodarstwa rolnego. Sąd administracyjny w wyroku z dnia 19 maja 2008 r. orzekł, że ,jeżeli grunty rolne w momencie ich nabycia znajdowały się w posiadaniu (dzierżawie), to nie może być podstaw do stosowania zwolnienia z podatku przewidzianego w art. 12 ust. 1 pkt 4 ustawy z 1984 r. o podatku rolnym. Zmiana tytułu prawnego - z dzierżawy na prawo własności - nie może spowodować, że grunty te wejdą w skład gospodarstwa rolnego, skoro już wcześniej w taki sposób były traktowane"23.

Prócz czynników prawnych wpływających na sytuację producenta rolnego w zakresie gospodarowania na dzierżawionych gruntach rolnych, duże znaczenie mają także czynniki pozaprawne, w tym: sytuacja ekonomiczna w rolnictwie, polityka państwa odnośnie do rolnictwa, ceny produktów rolnych, wysokość płatności z Unii Europejskiej, czynniki atmosferyczne wpływające ma wysokość i jakość pożytków naturalnych pozyskiwanych z gruntów rolnych. Odnotować należy także niską wiedzę stron umowy dzierżawy prywatnych gruntów rolnych na temat regulacji prawnych oraz ograniczony dostęp do doradztwa rolniczego.

Przykładowo przeprowadzone badania praktyczne wskazują, że dość często występują w stosunkach wiejskich wzory umów dzierżawy gruntów prywatnych przewidujące co prawda zawarcie umowy na czas oznaczony, ale pozwalające na swobodne rozwiązanie kontraktu z rocznym terminem wypowiedzenia. Mimo że w $2001 \mathrm{r}$. zmieniony został kodeks cywilny określający w art. 673 w ust. 3 w zw. z art. 694 kc., że jeżeli czas trwania dzierżawy jest oznaczony, zarówno wydzierżawiający, jak i dzierżawca mogą wypowiedzieć dzierżawę w wypadkach określonych w umowie, wspominane wzory kontraktów dzierżawy nie uległy zmianie i nadal funkcjonują na wsi. W oparciu o postanowienia umowne wydzierżawiający swobodnie wypowiadają dzierżawę, powodując tym samym naruszenie trwałości gospodarowania. Dzierżawcy z reguły z powodów finansowych albo nieznajomości swoich praw rezygnują z drogi sądowej celem odzyskania gruntów rolnych ${ }^{24}$.

Tak wyrok Wojewódzkiego Sądu Administracyjnego w Gliwicach z dnia 19 maja 2008 r. I SA/GI 1038/07, Lex nr 469648.

Przykładowo Sąd Apelacyjny w Poznaniu w wyroku z dnia 19 stycznia 2006 r. (I ACa 833/05) orzekł, że „przepis art. $673 \S 3$ kc. nie precyzuje, jak ma wyglądać określenie „wypadków”. Przyjmuje się jednak, że chodzi tu o wskazanie sytuacji, w których może nastapić wypowiedzenie. Z punktu widzenia językowego wypadek to „zdarzenie, wydarzenie, fakt”. Zatem postanowienia umowy, ograniczające się jedynie do stwierdzenia, że dopuszczalne jest wypowiedzenie umowy najmu (dzierżawy) zawartej na czas określony, byłyby niezgodne z omawianym przepisem. Nie jest zatem dopuszczalne wypowiedzenie takiej umowy, jeżeli nie wymieniono w niej wyraźnie przyczyn uzasadniających takie wypowiedzenie", Lex nr 186539. 
3. W dalszej części rozważania będą koncentrowały się na drugim elemencie trwałości gospodarowania na gruntach rolnych, tj. ochronie zdolności produkcyjnej przedmiotu dzierżawy. Polega ona na zabezpieczeniu właściwości wytwórczych gruntów rolnych oraz przystosowaniu budynków i urządzeń (stanowiących części składowe albo przynależności dzierżawionego gruntu rolnego) do wymagań prowadzonej działalności rolniczej. Podkreślić bowiem trzeba, że grunty rolne, ze względu na walory fizykochemiczne oraz przydatność produkcyjną, stanowią szczególny środek produkcji ${ }^{25}$. Niewłaściwe zabiegi agrotechniczne stosowane na gruntach mogą spowodować nie tylko obniżenie plonów, ale także pogorszenie jakości gleby $^{26}$. Z kolei budynki i urządzenia wykorzystywane do prowadzenia działalności rolniczej wymagają ciągłych napraw i ulepszeń oraz, co obecnie najważniejsze, przystosowania do wymogów Unii Europejskiej. W sytuacji ich niespełnienia dzierżawca może zostać nawet pozbawiony możliwości prowadzenia dotychczasowej działalności produkcyjnej. Pamiętać również trzeba, że dla dzierżawcy, który chce maksymalnie korzystać z przedmiotu dzierżawy, istotne jest zwłaszcza osiąganie optymalnych dochodów z prowadzonej działalności rolniczej w czasie trwania dzierżawy gruntów rolnych. Z kolei wydzierżawiający zainteresowany jest głównie zachowaniem zdolności produkcyjnej przedmiotu dzierżawy na przyszłość, a więc na czas przypadający po zakończeniu umowy.

Wytwarzając i pobierając pożytki naturalne z gruntu rolnego, dzierżawca może w sposób istotny oddziaływać na jego substancję i zdolność produkcyjną. Zależnie od sposobu tego oddziaływania, rzecz może pozostać w stanie nadającym się do dalszego z niej korzystania albo stan ten może ulec pogorszeniu ${ }^{27}$. W świetle art. 696 kc. dzierżawca powinien swoje prawo do używania przedmiotu dzierżawy i pobierania pożytków wykonywać zgodnie z wymaganiami prawidłowej gospodarki. W kodeksie cywilnym nie ma jednak bliższego określenia, o jakie wymogi prawidłowej gospodarki chodzi. Brak też podanych przykładowo działań, jakie dzierżawca winien podejmować w celu realizacji tych wymogów ${ }^{28}$. Zaznaczyć trzeba, że pojęcie „prawidłowej gospodarki” występuje także w kilku innych przepisach kodeksu cywilnego. Art. 53 kc. i art. 213 kc. odsyłają do ,zasad prawidłowej gospodarki”, natomiast w świetle art. $256 \mathrm{kc}$. użytkownik powinien wykonywać swoje prawo zgodnie $\mathrm{z}$,wymaganiami prawidłowej gospodarki”. Jednak i te przepisy nie zawierają wyjaśnienia omawianego pojęcia.

Tak T. Kurowska, Ochrona gruntów rolnych, (w:) Prawo rolne, pod red. A. Stelmachowskiego, Warszawa 2006, s. 253; por. P. Czechowski, Ochrona gruntów rolnych, (w:) P. Czechowski, M. Korzycka-lwanow, S. Prutis, A. Stelmachowski, Polskie prawo rolne na tle ustawodawstwa Unii Europejskiej. Warszawa 1997, s. 359 i n. Zob. M. Błażejczyk, Ochrona prawna gruntów rolnych. Warszawa 1967, s. 86-87. pod red. J. Panowicz-Lipskiej. Warszawa 2004, s. 182. Zob. szerzej W. Pańko, Dzierżawa gruntów rolnych. Warszawa 1975, s. 79-80. 
Nie ulega wątpliwości, że tak ogólnie określone wymagania wobec dzierżawcy należy skonkretyzować w zależności od dziedziny gospodarczej. Inne będą wymagania w odniesieniu do pojedynczej działki dzierżawionego gruntu rolnego, inne do gospodarstwa rolnego jako zorganizowanej całości gospodarczej. Można zatem przyjąć, że dzierżawca wykonuje swoje prawo do używania i pobierania pożytków zgodnie z wymaganiami prawidłowej gospodarki, podejmując działania, które można uznać za gospodarczo efektywne zarówno z punktu widzenia interesów stron umowy, jak i interesu społecznego. Kryterium prawidłowej gospodarki nie może być ujmowane abstrakcyjnie, lecz powinno być ustalane w konkretnych okolicznościach, z uwzględnieniem gospodarczych i pozagospodarczych właściwości przedmiotu dzierżawy ${ }^{29}$, jednakże $\mathrm{z}$ pominięciem osobistych kwalifikacji i możliwości dzierżawcy ${ }^{30}$.

Zważywszy na ogólną regulację w kodeksie cywilnym, można przyjąć, że art. 696 kc. stwarza jedynie ramy, w których dzierżawca ma wykonywać swoje prawo. Pewne wskazówki, a niekiedy nawet obowiązki w zakresie prowadzenia prawidłowej gospodarki określone zostały w pozakodeksowych aktach prawnych. Wspomnieć trzeba przede wszystkim o ustawie z 3 lutego 1995 r. o ochronie gruntów rolnych i leśnych ${ }^{31}$, regulującej zasady ochrony gruntów rolnych i leśnych oraz rekultywacji i poprawiania wartości użytkowej gruntów. Do producenta rolnego prowadzącego działalność rolniczą mają zastosowanie również przepisy ustawy z dnia 27 kwietnia $2001 \mathrm{r}$. Prawo ochrony środowiska ${ }^{32}$ dotyczące ochrony poszczególnych elementów środowiska. $Z$ uwagi na specyfikę działalności rolniczej na naruszenie najbardziej narażone są wody, powierzchnia ziemi oraz rośliny i zwierzęta. Według art. 101 wyżej wymienionego aktu prawnego ochrona powierzchni ziemi polega na zapewnieniu jej najlepszej jakości, w szczególności poprzez: racjonalne gospodarowanie, zachowanie wartości przyrodniczych i możliwości produkcyjnego wykorzystania, utrzymania jakości gleby i ziemi powyżej lub co najmniej na poziomie wymaganych standardów.

Od czasów uzyskania członkostwa Polski w Unii Europejskiej zmianie uległy także zasady prowadzenia działalności na dzierżawionych gruntach rolnych w przypadku korzystania ze środków unijnych. Początkowo szeroki katalog obowiązków odnosił się przede wszystkim, do beneficjentów korzystających z programów zawartych w ramach II filara Wspólnej Polityki Rolnej. Wpisywał się on w nurt zwią-

Zob. J. Szachułowicz, (w:) Kodeks cywilny. Komentarz, t. 2, Warszawa 2003, s. 552.

Tak A. Lichorowicz, Dzierżawa, (w:) System Prawa Prywatnego, t. 8, Prawo zobowiązań..., s. 182. Inaczej J. Szachułowicz, który uważa, że dla określenia poziomu zasad prawidłowej gospodarki należy brać pod uwagę także zawodowe i etyczne kwalifikacje dzierżawcy, gdyż osoba dzierżawcy ma decydujące znaczenie dla jego wyboru. Inne będą wymagania i oczekiwania od dzierżawcy doświadczonego i wykształconego, a inne w stosunku do osoby, która nie dysponuje tymi przymiotami; zob. J. Szachułowicz, (w:) Kodeks cywilny..., t. 2, s. 292294. 
zany ze zrównoważonym gospodarowaniem zasobami naturalnymi poprzez ochronę środowiska. Chodziło przede wszystkim o programy rolnośrodowiskowe i wspieranie działalności rolniczej na obszarach o niekorzystnych warunkach gospodarowania (ONW). Wybierając konkretny pakiet, dzierżawca zobowiązuje się do prowadzenia działalności zgodnie z wymaganiami określonymi w aktach prawnych, np. w ramach rolnictwa zrównoważonego obowiązki polegają m.in. na przestrzeganiu prawidłowego doboru i następstwa roślin, przy zastosowaniu co najmniej trzech gatunków roślin, każdego z innej grupy roślin, z wyłączeniem roślin wieloletnich; opracowaniu co roku planu nawozowego na podstawie bilansu azotu oraz aktualnej chemicznej analizy gleby, z określeniem zawartości P, K, Mg i potrzeb wapnowania gleby.

Jak wiadomo, polscy rolnicy mogą korzystać z płatności w ramach systemów wsparcia bezpośredniego. Przysługują one producentowi faktycznie uprawiającemu grunty, a zatem dzierżawcy. W świetle art. 7 ust. 6 ustawy z dnia 26 stycznia 2007 r. o płatnościach w ramach systemów wsparcia bezpośredniego ${ }^{33} \mathrm{w}$ przypad$\mathrm{ku}$, gdy działka rolna stanowi przedmiot posiadania samoistnego i posiadania zależnego, płatności obszarowe przysługują posiadaczowi zależnemu. Oznacza to, że strony nie mogą na mocy postanowienia umownego wprowadzić zastrzeżenia, że wniosek o płatności złoży wydzierżawiający i to jemu przysługują środki unijne ${ }^{34}$. W wielu orzeczeniach sądy administracyjne podkreślały, że ,,[...]pojęcie posiadania gruntów rolnych, w rozumieniu ustawy z 2007 r. o płatnościach w ramach systemów wsparcia bezpośredniego należy rozumieć jako faktyczne użytkowanie gruntów rolnych. Za takim jego rozumieniem przemawia to, że celem płatności (dopłat) jest dofinansowanie do produkcji rolnej, pomoc rolnikom, którzy faktycznie użytkują będące $w$ ich posiadaniu grunty rolne, a nie tylko są formalnymi posiadaczami gruntów, co do których wnioskują o dopłaty"35.

Uzyskanie jednolitej płatności obszarowej i innych określonych w wymienionym akcie prawnym łączy się z obowiązkiem spełnienia szeregu wymagań. Początkowo obowiązkiem beneficjentów było utrzymanie gruntów rolnych w dobrej kulturze rolnej, przy zachowaniu wymogów ochrony środowiska. Zostały one zawarte w rozporządzenia Ministra Rolnictwa i Rozwoju Wsi z dnia 7 kwietnia 2004 r. w sprawie minimalnych wymagań utrzymywania gruntów rolnych w dobrej kulturze rolnej ${ }^{36}$. W kolejnych latach wprowadzanie w ramach Wspólnej Polityki Rolnej

Tekst jedn. Dz.U. z 2008 r. Nr 170, poz. 1051.

W wyroku z dnia 22 grudnia 2010 r. Wojewódzki Sąd Administracyjny w Gdańsku (I SA/Gd 334/10) orzekł, że „przesłanki niezbędne do otrzymania płatności określa akt prawny i nie jest prawnie skuteczna umowa zawarta pomiędzy właścicielem a dzierżawcą ustalająca, który z nich wystapi z wnioskiem o przyznanie płatności bezpośrednich. Uzyskanie płatności następuje poprzez wydanie decyzji w stosunku do określonej osoby, po spełnieniu przez tę osobe ustawowych warunków", LEX nr 747858.

Tak wyrok Wojewódzkiego Sądu Administracyjnego w Gdańsku z dnia 13 października 2010 r. I SA/Gd 332/10, LEX nr 747856.

Dz.U. Nr 65, poz. 600 z późn. zm. 
zasad wzajemnej zgodności (ang. cross-compliance) spowodowało powiązanie prawa do płatności bezpośrednich ze spełnianiem przez beneficjentów dodatkowych wymagań. Odnoszą się one do zagadnienia ochrony środowiska naturalnego, zdrowia publicznego, zdrowia zwierząt i zdrowotności roślin. Według obecnie obowiązującego rozporządzenia Ministra Rolnictwa i Rozwoju Wsi z dnia 11 marca 2010 r. w sprawie minimalnych norm ${ }^{37}$ pobierającemu płatności bezpośrednie zabrania się m.in. wypalania gruntów rolnych, wykonywania zabiegów uprawowych ciężkim sprzętem rolniczym w okresie wysycenia profilu glebowego wodą. W przypadku gruntów ornych producent rolny musi prowadzić na nich uprawę roślin lub ugorować, przy czym dla pszenicy, żyta, jęczmienia i owsa ten sam gatunek rośliny może być uprawiany na tej samej powierzchni w ramach działki ewidencyjnej nie dłużej niż 3 lata.

$\mathrm{Z}$ dniem 15 marca 2011 r. weszła w życie nowelizacja z 4 lutego 2011 r. ustawy z 26 stycznia 2007 r. o płatnościach w ramach systemów wsparcia bezpośredniego $^{38}$ wprowadzająca m.in. zasady kontroli wymogów wzajemnej zgodności. Kontrola wymogów z obszaru B określonych w rozporządzeniu unijnym nr 73/2009 ${ }^{39}$ została powierzona: Agencji Restrukturyzacji i Modernizacji Rolnictwa w zakresie zdrowia roślin oraz zdrowia publicznego w odniesieniu do żywności pochodzenia roślinnego oraz Inspekcji Weterynaryjnej w zakresie obejmującym zdrowie zwierząt i zgłaszanie chorób.

Można uznać, że na zasady i metody prowadzenia działalności rolniczej na dzierżawionych gruntach rolnych istotny wpływ mają wymagania wynikające $\mathrm{z}$ aktów prawnych dotyczących Wspólnej Polityki Rolnej. Co prawda korzystanie ze środków unijnych nie jest obowiązkowe, ale obecnie ogromnie trudno byłoby prowadzić gospodarstwo bez pomocy publicznej. Ponad $90 \%$ producentów rolnych korzysta z jednolitej płatności obszarowej, a niestosowanie się do wymagań wynikających z różnych aktów prawnych łączy się z konsekwencjami finansowymi.

Z punktu widzenia zachowania zdolności produkcyjnej przedmiotu dzierżawy niezmiernie istotne są zasady wykonywania napraw i ulepszeń przedmiotu dzierżawy. Mowa tu przede wszystkim o naprawach i ulepszeniach budynków oraz urządzeń koniecznych do prowadzenia działalności rolniczej, stanowiących części składowe albo przynależności dzierżawionego gruntu rolnego. Dodać również należy, że kwestie te są szczególnie istotne dla praktyki, ponieważ brak precyzyjnych przepisów rodzi dużo problemów. Zgodnie z art. 697 kc. dzierżawca ma obowiązek do- 
konywania napraw niezbędnych do zachowania przedmiotu dzierżawy w stanie niepogorszonym. $\mathrm{Z}$ drugiej strony wydzierżawiający ma obowiązek utrzymywania przedmiotu dzierżawy w stanie zdatnym do użytku przez cały czas trwania dzierżawy (art. 662 kc. w związku z art. 694 kc.). Oba wymienione przepisy mają na celu zachowanie substancji przedmiotu dzierżawionego.

W kodeksie cywilnym brakuje definicji „naprawy”. Są one związane z bieżącą, prawidłową eksploatacją przedmiotu dzierżawy; na ich dokonywanie nie jest potrzebna zgoda wydzierżawiającego. Są one wykonywane głównie w interesie dzierżawcy, by przedmiot dzierżawy pozostawał w stanie umożliwiającym używanie i pobieranie pożytków. W czasie trwania stosunku dzierżawy bardzo często dzierżawca poprzez inwestycje lub naprawy nie tylko zachowuje, ale i podwyższa wartość użytkową przedmiotu dzierżawy. Obowiązujący kodeks cywilny w przepisach dotyczących dzierżawy nie określa, co należy rozumieć przez „ulepszenie” przedmiotu dzierżawy. W praktyce często pojawiają się problemy z zakwalifikowaniem nakładów dokonanych przez dzierżawcę, zgodnie z wymaganiami prawidłowej gospodarki, jako naprawy czy ulepszenia. Uzasadnione wydaje się oparcie ich na kryterium obiektywnego, trwałego podwyższenia wartości użytkowej przedmiotu dzierżawy w wyniku działania dzierżawcy ${ }^{40}$. Jednocześnie należy pamiętać, że według art. 696 kc. na dzierżawcy ciąży obowiązek zachowania przeznaczenia przedmiotu dzierżawy, a zatem w przypadku ulepszeń zmieniających to przeznaczenie konieczne jest uzyskanie zgody wydzierżawiającego. Powstaje podstawowe pytanie. Czy dzierżawca, który dokonał ulepszeń przedmiotu dzierżawy, może domagać się od wydzierżawiającego odpowiedniej sumy pieniężnej z tego tytułu?

Według art. 676 kc. w związku z art. 694 kc., jeżeli dzierżawca ulepszył rzecz dzierżawioną, wydzierżawiający (w razie braku odmiennej umowy) może według swego wyboru: albo zatrzymać ulepszenie za zapłatą sumy odpowiadającą jego wartości w chwili zwrotu, albo zażądać przywrócenia stanu poprzedniego. W wyroku z dnia 8 lipca 2010 r. Sądu Najwyższy ${ }^{41}$ potwierdził, że ,przepis art. 676 kc. ma zastosowanie w zakresie stosunku dzierżawy nieruchomości (art. 694 kc.), mimo odmienności konstrukcyjnych umowy najmu i umowy dzierżawy oraz innych funkcji gospodarczych tych umów. Sąd stwierdził także, że roszczenie dzierżawcy o zwrot wartości ulepszeń (tzw. nakładów ulepszających) powstaje dopiero po pojawieniu się dwóch zdarzeń: zwrotu przedmiotu dzierżawy (nieruchomości) i wykonaniu przez wydzierżawiającego prawa wyboru określonego w art. $676 \mathrm{kc}$. (zatrzymanie ulepszeń za zapłatę ich wartości albo przywrócenie stanu poprzedniego przedmiotu dzierżawy)".

40 Zob. W. Pańko, Dzierżawa gruntów rolnych, Warszawa 1975, s. 88.

41 Wyrok Sądu Najwyższego z dnia 26 czerwca 2008 r. II CSK 69/08, LEX nr 548800. 
Zagwarantowanie wyboru przez wydzierżawiającego w odniesieniu do ulepszeń przedmiotu dzierżawy gruntów rolnych, tj. zatrzymanie ulepszenia za zapłatą sumy odpowiadającej jego wartości w chwili zwrotu albo zażądanie przywrócenia stanu poprzedniego zapłaty w niektórych sytuacjach trudno uznać za korzystne rozwiązanie $\mathrm{w}$ aspekcie zachowania zdolności produkcyjnej przedmiotu dzierżawy. Chodzi mianowicie o ulepszenia wykonywane w ramach prowadzenia prawidłowej gospodarki na dzierżawionym gruncie, niezmieniające takiego przeznaczenia i zarazem nienaruszające treści kontraktu. Po uzyskaniu przez Polskę członkostwa w Unii Europejskiej producenci rolni, aby kontynuować prowadzoną działalność rolniczą, zmuszeni byli często do dostosowania przedmiotu dzierżawy, a szczególnie budynków i urządzeń, do wymogów unijnych. Chodziło zwłaszcza o osiągnięcie odpowiednich standardów sanitarnych, weterynaryjnych i fitosanitarnych z zakresu ochrony środowiska. Przykładowo producenci mleka musieli dostosować warunki utrzymania krów mlecznych do wymagań sanitarnych, a wydzielone pomieszczenia do przechowywania mleka odpowiednio wyposażyć w urządzenia sanitarne. W niektórych sytuacjach dzierżawcy zobowiązywali się w umowie dzierżawy do dalszego prowadzenia działalności w zakresie produkcji mleka czy kontynuacji udziału w programie rolnośrodowiskowym.

Zważywszy, że modernizacji przedmiotu dzierżawy mającej na celu dostosowanie do wymogów unijnych nie można zakwalifikować jako naprawy, do których wykonania zobowiązany jest dzierżawca zgodnie z art. 697 kc., powstaje pytanie, czy dzierżawca, który dokonał ulepszeń w ramach prawidłowej gospodarski i na podstawie obowiązujących przepisów, może domagać się zwrotu kosztów za ulepszenia. W takiej sytuacji jako zasadne wydaje się przyjęcie, że wydzierżawiający nie powinien mieć prawa do powoływania się na przewidzianą przez art. $676 \mathrm{kc}$. w związku z 694 kc. możliwość żądania przywrócenia stanu poprzedniego przedmiotu dzierżawy. Tym samym powstaje wątpliwość, na jakich zasadach powinno być dokonywane rozliczenie za dokonane ulepszenia. Wydaje się, że w takim przypadku winny mieć zastosowanie przepisy o bezpodstawnym wzbogaceniu. Rozmiary rekompensaty należnej dzierżawcy powinno się wtedy ustalać na zakończenie stosunku dzierżawy, proporcjonalnie do wzrostu wartości rzeczy, będącej wynikiem poczynionych przez dzierżawcę nakładów. Jednak należy wyraźnie podkreślić, że takie rozwiązanie nie wynika bezpośrednio z przepisów i dzierżawca może mieć problemy z odzyskaniem zainwestowanych w przedmiot dzierżawy pieniędzy. Dlatego zawierając umowę dzierżawy, najlepiej uzgodnić z wydzierżawiającym zasady rozliczeń za dokonanie w przyszłości ulepszenia. Jest to tym bardziej istotne, gdy dzierżawca zamierza starać się o dotacje unijne, a ich uzyskanie łączy się z modernizacją przedmiotu umowy.

Jeżeli chodzi o dzierżawę z Zasobu WRSP, to gdy dzierżawca zdecyduje się na dokonanie inwestycji (ulepszenia), powinien - zgodnie z umową dzierżawy - wy- 
stąpić ze stosownym wnioskiem do dyrektora oddziału terenowego ANR i przedłożyć wymagane dokumenty. Wnioski dzierżawców o zgodę na dokonanie inwestycji rozpatruje komisja powołana przez dyrektora oddziału terenowego ANR, w skład której wchodzi m.in. osoba z uprawnieniami budowlanymi lub rzeczoznawca majątkowy. Po wyrażeniu zgody zawarta zostaje umowa pomiędzy wydzierżawiającym a dzierżawcą. W praktyce wykorzystywane są dwa rodzaje wzorów takich umów - wzór umowy o wykonanie inwestycji finansowanej przez dzierżawcę lub wzór umowy o inwestycję prowadzoną na koszt wymienionej państwowej osoby prawnej $^{42}$. Jako zasadę przyjmuje się, że dzierżawca pokrywa koszty inwestycji przy zapewnieniu ze strony ANR, że zachowa ona poczynione ulepszenie za zapłatą sumy odpowiadającej jego wartości

4. Dokonując krótkiego podsumowania, należy stwierdzić, że przepisy nie zapewniają dzierżawcy wystarczającej ochrony trwałości gospodarowania na dzierżawionych gruntach rolnych. Jednak jej zakres jest uzależniony od statusu wydzierżawiającego (czy jest to ANR, jednostka samorządu terytorialnego czy osoba prywatna) oraz dzierżawcy (tj. czy producent rolny jest rolnikiem indywidualnym czy też wielkoobszarowym). Jednocześnie należy wyjaśnić, że na stabilizację dzierżawy jako formy władania gruntami rolnymi wpływają nie tylko przepisy prawne, ale także polityka rolna w zakresie rolnictwa oraz sytuacja gospodarcza. Przykładowo w pierwszym okresie funkcjonowania Agencji po przejęciu państwowych przedsiębiorstw gospodarki rolnej zachodziła konieczność szybkiego przekazania gruntów, zabudowań i inwentarza. Dlatego oddawano w dzierżawę duże obszary zorganizowanych gospodarstw rolnych. Z kolei wejście w życie ustawy z 11 kwietnia 2003 r. o kształtowaniu ustroju rolnego wprowadziło regulacje korzystne dla rozwoju dzierżawy w gospodarstwach rodzinnych, a znacznie ograniczało możliwości powiększania powierzchni gospodarstw przez rolników wielkoobszarowych oraz osoby prawne. Obecnie, w związku z dużym zainteresowaniem nabywania gruntów rolnych przez rolników indywidualnych, zmniejszaniem się powierzchni gruntów o charakterze rolnym w Polsce oraz perspektywą zakończenia okresów przejściowych na zakup nieruchomości przez cudzoziemców, uchwalona została nowelizacja z 16 września 2011 r. do ustawy o gospodarowaniu nieruchomościami rolnymi Skarbu Państwa. Przepisy tego aktu prawnego znacznie osłabiają znaczenie dzierżawy państwowej i naruszą trwałość gospodarowania na dzierżawionych gruntach rolnych gospodarstw wielkoobszarowych.

Specyficzna sytuacja w zakresie prawnej ochrony trwałości gospodarowania na dzierżawionych gruntach rolnych dotyczy właśnie dzierżawy nieruchomości z Zasobu WRSP. Z jednej strony ustawa z dnia 19 października 1991 r. i wydane na 
jej podstawie akty wykonawcze wprowadziły szerszy katalog instrumentów ochrony trwałości stosunku prawnego dzierżawy w porównaniu do kodeksu cywilnego, z drugiej jednak dzierżawcy nieruchomości z Zasobu WRSP napotykają na bariery, jeżeli chodzi o nabycie własności dzierżawionych gruntów rolnych. To ostatnie stwierdzenie odnosi się szczególnie do dzierżawców gospodarstw wielkoobszarowych. Dzierżawa jako forma gospodarowania gruntami rolnymi państwowymi będzie coraz mniej stabilna.

Odnosząc się z kolei do dzierżawy gruntów prywatnych, należy podkreślić, że przepisy prawne nie zapewniają odpowiedniej ochrony producentowi rolnemu. Większa stabilizacja tej formy władania gruntami może wynikać z postanowień umowy. W naszym systemie prawnym brakuje podziału na dzierżawę długoterminową, krótkoterminową, dzierżawę ,zawodową”. Sporo kłopotów wiąże się z przedłużaniem dzierżawy na następny okres dzierżawny oraz kwestą napraw i ulepszeń. Szersza prawna ochrona trwałości gospodarowania na dzierżawionych gruntach rolnych występuje w odniesieniu do gospodarstw rodzinnych. Wynika to głównie z polityki państwa w zakresie rolnictwa. Podstawę bowiem ustroju państwa stanowi gospodarstwo rodzinne i ustawodawca stara się wprowadzać regulacje korzystne właśnie dla ich rozwoju. Potwierdza to przyznanie prawa pierwokupu dzierżawionej nieruchomości rolnej rolnikowi indywidualnemu, prowadzącemu gospodarstwo rodzinne, czy zasady przeprowadzania przetargów ograniczonych przez ANR. Ponadto z niektórych kredytów oferowanych przez ARiMR na zakup dzierżawionych gruntów rolnych mogą korzystać tylko rolnicy indywidualni prowadzący gospodarstwo rodzinne, m.in. z kredytu na zakup nieruchomości rolnych przeznaczonych na utworzenie lub urządzenie gospodarstwa rodzinnego w rozumieniu ustawy z dnia 11 kwietnia $2003 \mathrm{r}$.

Warto dodać, że z jednej strony prawodawca zauważa, że dzierżawa jest popularną i potrzebną formą gospodarowania gruntami rolnymi na wsi. Świadczą o tym chociażby nowelizacje niektórych rozporządzeń Ministra Rolnictwa i Rozwoju Wsi uwzględniające dzierżawę jako formę powiększenia gospodarstwa przez młodego rolnika ${ }^{43}$ czy osobę obejmującą gospodarstwo od przyszłego rencisty strukturalnego $^{44}$. Z drugiej jednak strony przeprowadzone krótkie rozważania potwierdzają, że

Według rozporządzenia Ministra Rolnictwa i Rozwoju Wsi z dnia 17 października 2007 r. w sprawie szczegółowych warunków i trybu przyznawania pomocy finansowej w ramach działania „Ułatwianie startu młodym rolnikom" objętego Programem Rozwoju Obszarów Wiejskich na lata 2007-2013 (Dz.U. Nr 200, poz. 1443) przy ustalaniu minimalnej powierzchni użytków rolnych w gospodarstwie, o której mowa w $\S 2$ ust. 1 pkt 1 lit. a tiret pierwsze rozporządzenia, sumuje się powierzchnię użytków rolnych stanowiących przedmiot: 1) własności; 2) użytkowania wieczystego; 3) dzierżawy z Zasobu Własności Rolnej Skarbu Państwa lub od jednostek samorzadu terytorialnego, jeżeli umowa dzierżawy została zawarta na czas nieoznaczony lub na okres co najmniej 5 lat, jednak nie krótszy niż do dnia upływu 5 lat od dnia wypłaty pomocy; 4) dzierżawy od podmiotów innych niż wymienione w pkt 3, jeżeli umowa dzierżawy została zawarta: a) w formie aktu notarialnego albo ma datę pewna, b) na okres co najmniej 10 lat. runków i trybu przyznawania pomocy finansowej w ramach działania „Renty strukturalne” objętego Programem 
wysuwany od lat postulat wprowadzenia odrębnych przepisów dotyczących dzierżawy gruntów rolnych nadal jest aktualny. Na szczególną uwagę zasługują dzieła prof. A. Lichorowicza dotyczące wprowadzenia nowego modelu dzierżawy gruntów rolnych $^{45}$. Co prawda znaczenie dzierżawy z Zasobu WRSP będzie coraz mniejsze, ale nadal ponad 1,50 mln gruntów z Zasobu WRSP jest w posiadaniu dzierżawców. Poza tym coraz większą popularnością cieszy się dzierżawa gruntów prywatnych i komunalnych. Zasadne zatem wydaje się wprowadzenie instrumentów zabezpieczających stabilne gospodarowanie na dzierżawionych gruntach rolnych.

Na koniec warto także wysunąć wniosek de lege ferenda zmiany art. 28 ust. 4 ustawy o ubezpieczeniu społecznym rolników ${ }^{46}$. Co prawda w jego świetle oddanie gruntów rolnych wchodzących w skład gospodarstwa rolnego w długoterminową dzierżawę uznaje się za zaprzestanie prowadzenia działalności rolniczej, ale nie może ono nastąpić m.in. na rzecz zstępnych lub pasierbów. Ograniczenie to powoduje, że przekazanie gruntów na rzecz tych osób musi nastąpić w sposób trwały, np. w formie darowizny, co w niektórych przypadkach nie jest korzystne dla rolników. W wielu państwach europejskich popularne jest oddawanie gruntów rolnych w długoterminową dzierżawę (10 i więcej lat) na rzecz rodziny. W takiej sytuacji przekazujący producent rolny prócz emerytury może także uzyskiwać czynsz dzierżawny, co zwiększa jego dochody. Takie rozwiązanie byłoby bardzo zasadne w polskich warunkach, a to z uwagi na bardzo niskie świadczenie emerytalne rolników, wynoszące $\mathrm{z}$ reguły 700-800 zł. Przeprowadzone badania praktyczne na wsi wskazują także, że stosunkowo często dochodzi do zwrotu darowanych gruntów rolnych wskutek odwołania darowizny na podstawie art. 898 kodeksu cywilnego z powodu rażącej niewdzięczności obdarowanego. Problemy wynikają ze złej sytuacji finansowej byłych rolników oraz braku opieki i pomocy darczyńcom ze strony obdarowanych. Zwrot gruntów rolnych przekazanych na podstawie darowizny negatywnie wpływa na trwałość gospodarowania na gruntach rolnych. Dlatego, biorąc pod uwagę sytuację społeczną i finansową występującą na wsi, w wielu przypadkach oddanie gruntów w długoterminową dzierżawę na rzecz zstępnych i traktowanie jej jako zaprzestanie działalności rolniczej w świetle ustawy o ubezpieczeniu społecznym rolników byłoby lepszym rozwiązaniem ${ }^{47}$.

Rozwoju Obszarów Wiejskich na lata 2007-2013 (Dz.U. Nr 109, poz. 750).

A. Lichorowicz, P. Czechowski, Dzierżawa gruntów rolnych w świetle standardów europejskich, „Podatki i Prawo Gospodarcze UE” 1999, nr 6, s. 2-4; A. Lichorowicz, O nowy model dzierżawy rolniczej (propozycje zmian aktualnej regulacji prawnej dzierżaw rolnych), (w:) Dzierżawa ziemi jako czynnik przemian struktury agrarnej w Polsce (pod red. W. Ziętary), Warszawa 1999; tenże, Potrzeba prawnego uregulowania dzierżawy rolnej w Polsce (na podstawie doświadczeń krajów Unii europejskiej), „Przegląd Prawa Rolnego” 2010, nr 2. nadużywane celem uzyskania części uzupełniającej emerytury czy renty z tytułu niezdolności do pracy. Jednak KRUS może zostać wyposażony w instrumenty kontrolne i możliwość zastosowania sankcji wobec podmiotów postępujących niezgodnie z przepisami. Chodzi mianowicie o rolników, którzy przekazując gospodarstwo rolne w dzierżawę, nadal będą w nim pracować. 


\section{Legal issues of farming on leased agricultural land}

Key words: agricultural land lease, manufacturing capacity, Agricultural Property Agency

The purpose of the paper was to answer the question whether the legal regulations ensure an agricultural producer (lessee) sufficient stability in terms of farming, namely in terms of running a stable agricultural activity. According to the author of this article, this stability consists of two elements: ensuring the agricultural producer continuity of possession and enjoyment of the profits as well as guaranteeing manufacturing capacity of the subject of the agricultural lease.

The article presents, among other things, the assessment of the influence of legal solutions included in Act of 16 September 2011 on changing Act on the management of agricultural property of the State Treasury on stability of the agricultural lease. It also analyzes questions relating to lease of private land and lease of land from the units of local governments. Moreover, the article focuses on the instruments protecting the manufacturing capacity of the subject of the lease, including EU regulations that make the obtaining of financial support subject to meeting numerous requirements concerning the treatments and maintaining good agricultural condition. The article also concentrates on the issues of amendments and improvements.

In the final part of the article the author has stated that research has confirmed that the legal regulations do not protect farming on leased agricultural land in a sufficient way. The current legal regulations on agricultural land lease do not correspond to the requirements of present situation in Poland. Therefore, de lege ferenda proposal has been put forward to change the provisions relating to the agricultural land lease. 